\title{
Forage Yield and Quality of Lablab (Lablab purpureus L. Sweet) Intercropped With Maize (Zea mays L.) With Flooded Irrigation System in the Semi-Arid Zone of Nigeria
}

\author{
M. R. Hassan ${ }^{1}$, J. T. Amodu ${ }^{2}$, I. R. Muhammad ${ }^{3}$, G. E. Jokthan ${ }^{4}$, S. B. Abdu ${ }^{1}$, B. Abdullahi ${ }^{1}$, H. Y. Adamu ${ }^{1}$, \\ A. Musa ${ }^{5}$ I. Sani ${ }^{1} \&$ T. T. Akpensuen ${ }^{6}$ \\ ${ }^{1}$ Department of Animal Science, Ahmadu Bello University, Zaria, Nigeria \\ ${ }^{2}$ National Animal Production Research Institute, Shika, Ahmadu Bello University, Zaria, Nigeria \\ ${ }^{3}$ Department of Animal Science, Bayero University, Kano, Nigeria \\ ${ }^{4}$ National Open University of Nigeria, Lagos, Nigeria \\ ${ }^{5}$ International Livestock Research Institute, Kano, Nigeria \\ ${ }^{6}$ Department of Animal Science, University of Jos, Nigeria \\ Correspondence: M. R. Hassan, Department of Animal Science, Ahmadu Bello University, PMB 1044, Zaria, \\ Nigeria. Tel: 234-080-6285-3385. E-mail: mrhassan@abu.edu.ng
}

Received: August 4, 2014 Accepted: September 1, 2014 Online Published: October 15, 2014

doi:10.5539/jas.v6n11p196 URL: http://dx.doi.org/10.5539/jas.v6n11p196

\begin{abstract}
An experiment was conducted in 2009, 2010 and 2011 dry seasons to investigate the use of lablab (Lablab purpureus L. Sweet) as alternative forage legume for use in maize-legume intercrop under 3 irrigation regimes. Lablab was harvested for forage yield from 6 to 18 weeks after seeding. Forage yield and quality of lablab at different ages of growth and irrigation frequency, as well as maize grain yield and yield components were measured. Plant height of maize and number of leaves of lablab were not affected $(\mathrm{P}>0.05)$ by years of trial. Plant stand count of lablab, number of leaves of maize, plant height of lablab, and LAI of maize and lablab differed $(\mathrm{P}<0.05)$ with years of trial. Irrigation frequency did not affect $(\mathrm{P}<0.05)$ number of leaves of maize and lablab. There were significant $(\mathrm{P}<0.05)$ interactions between age of cutting $\mathrm{x}$ year of trial $\mathrm{x}$ irrigation schedule on dry forage yield of lablab. Age of cutting had no effect $(\mathrm{P}>0.05)$ on forage $\mathrm{Mg}$ and $\mathrm{Na}$ contents of lablab. The CP contents of lablab at 15 and 18 WAS were lower $(\mathrm{P}<0.05)$ than the $\mathrm{CP}$ at 6 WAS. The forage CF, $\mathrm{NDF}, \mathrm{ADF}, \mathrm{EE}$ and NFE differed $(\mathrm{P}<0.05)$. Except ADF and Ca: $\mathrm{P}$, measured nutrients did not differ $(\mathrm{P}>0.05)$ with irrigation frequency. The maize grain yield was higher $(\mathrm{P}<0.05)$ in 2010 and $2011(1722-1726 \mathrm{~kg} / \mathrm{ha})$ than $2009(1412 \mathrm{~kg} / \mathrm{ha})$. Results from this study suggest that lablab could be introduced as a component crop in an intercropping system with maize under irrigation in Nigeria.
\end{abstract}

Keywords: intercrop, lablab forage yield, lablab forage quality, maize grain, growth parameters

\section{Introduction}

Mixed crop-livestock farming system is a typical characteristics of developing countries (Mpairwe et al., 2003). Cereal crops such as maize, sorghum and millet, and keeping of livestock (sheep, goats and cattle) and poultry are the main components of this type of mixed crop-livestock farming system. In Nigeria, such mixed crop-livestock production system is a common feature of the smallholder farmers, who have limited farmland resources. In most African countries, livestock farming systems rely on grazing natural pastures and crop residues for dietary energy and protein (Karachi, 1997). In Nigeria, the dietary energy $(2.4 \mathrm{Mcal} / \mathrm{kgDM})$ and protein $(5.6 \%)$ obtained from these sources, particularly in the dry season (Birnin Yauri and Umar, 2014), are generally too low to meet the nutrient requirements of ruminant livestock for maintenance $(2.7 \mathrm{Mcal} / \mathrm{kgDM}$ and $11.6 \% \mathrm{CP}$ ) and production (2.9 Mcal $/ \mathrm{kgDM}$ and $26.2 \% \mathrm{CP}$ ) (NRC, 1985). The use of protein and other energy rich feeds in the form of concentrates to supplement the poor quality forage and crop residues is an option for the farmers in meeting the nutrient needs of their ruminant livestock. However, these concentrates are expensive to the farmers. Cheaper sources are therefore needed for optimum performance of ruminant livestock in most parts Nigeria. 
Lablab (Lablab purpureus L. Sweet) is one of the most popular leguminous forage species in the world (Purseglove, 1968; Murphy \& Colucci, 1999; Pengelly \& Maass, 2001; Ayishi et al., 2004; Murungweni et al., 2004). Lablab is a dual-purpose legume, which means it can be traditionally grown as a pulse crop for human consumption, used as a fodder for livestock or as green manure. The lifespan of lablab has been found to extend into early dry season (November-February) in Zaria, northern Nigeria (Nworgu \& Ajayi, 2005). It is a legume which produces high quality conserved feed (4 tDM/ha and $120 \mathrm{gCP} / \mathrm{kgDM}$ ) (Agishi, 1983; Titterton and Bareeba, 1999; Amodu et al., 2005).

Maize (Zea mays) is an important cereal crop in Nigeria. It is used as a main source of diet by many people in both rural and urban areas (Iken \& Amusa, 2004). Intercropping cereal crops with leguminous crops such as cowpea (Vigna unguiculata), groundnut (Arachis hypogea) and soybean (Glycine max) has been an old practice among the smallholder farmers in Nigeria, especially under rain fed condition (Egharevba, 1984; Olufajo, 1995). In many states in northern Nigeria where irrigation facilities exist, small scale farmers cultivate maize under irrigation in the dry season for commercial purposes (Nasiru \& Odusina, 2008; Sani et al., 2008). Crop residues from irrigated maize are used as livestock feeds during the critical 5 dry months (January - May) of the year when feed scarcity is at its peak. Despite vast land, human and water resources in northern Nigeria, these resources are not properly harnessed for agricultural production (Manyong et al., 2003). In north-western states such as Kano, Kaduna, Zamfara and Sokoto, states, flood irrigation for vegetable and grain crops such as tomatoes (Lycopersicon esculentum), water melon (Citrullus lanatus), okro (Hibiscus esculentus L), sweet potatoes (Ipomoea batatas), rice (Oryza sativa) and maize (Zea mays) is a common practice. However, intercropping vegetable and other grain crops such as maize with lablab, or any other forage legume such as cowpea (Vigna unguiculata) or groundnut (Arachis hypogaea) under irrigation is not a common practice among the smallholder farmers in this part of Nigeria. Lablab is one of the few neglected crops that is not cultivated by farmers in Nigeria in both rainy and dry seasons, even though some studies in Nigeria highlighted its potentials for crop-livestock integration (Shehu et al., 2001a, 2001b, 2001c; Amodu et al., 2003; Amodu et al., 2004; Nworgu \& Ajayi, 2005). Studies have shown that when ruminant animals were fed with fibrous crop residues and forage materials such as maize stover supplemented with lablab forage, their performance generally improved (Kabirizi et al., 2007). The cost of fertility of a companion cereal crop can be reduced through the activities of nitrogen fixation by lablab (Abubakar et al., 2006). Since irrigation activities are gradually gaining popularity among smallholder farmers in north-western states of Nigeria (Soneye, 2014), it is imperative to explore the possibility of integrating maize and lablab under irrigation in the Sudano-Sahelian zone of Nigeria. Intercropping a high yielding and ecologically adapted cereal/forage crop mixtures such as maize with lablab under irrigation will help to increase the income of livestock farmers through increase in yields of maize cobs and high quality fodder for silage or hay, to supplement the low quality crop residues offered during the dry season (Armstrong et al., 2008). The objective of this study was to investigate the performance of maize and lablab intercrop mixtures under irrigation in northern Nigeria.

\section{Materials and Methods}

\subsection{Site Description}

The experiment was conducted during the 2009, 2010 and 2011 dry seasons, within the premises of Kadawa Irrigation Research Station, Kano, in the semi-arid zone of Nigeria. Kadawa lies on Latitude $11^{\circ} 39^{\prime} \mathrm{N}$ and Longitude $08^{\circ} 20^{\prime} \mathrm{E}$. It has an altitude of $500 \mathrm{~m}$ above sea level (Onyibe, 2005; Sani et al., 2014). Kadawa climate is characterized by a well-defined wet (May - October) and dry (November - April) season (Abu \& Malgwi, 2011). The soil of the experimental site was characterized as sandy loam with moderately acidic $\mathrm{pH}$ (5.95). Other physical and chemical properties of the soil include: organic matter $(2.61 \%)$, total $\mathrm{N}(0.05 \%)$, available $\mathrm{P}$ (54.87\%), exchangeable K $(0.24 \mathrm{Cmol} / \mathrm{kg})$, Cation Exchange Capacity $(7.57 \mathrm{Cmol} / \mathrm{kg})$, soil temperature $\left(25^{\circ} \mathrm{C}\right)$ and volumetric soil moisture at $-33 \mathrm{kPa}(0.30 \%)$ (Abu \& Malgwi, 2011; Adamu et al., 2014), Metrological observations for the years of the trial at Kadawa are shown in Table 1. The results of soil samples taken before land preparation and planting in each of the cropping seasons are shown in Table 2. 
Table 1. Metrological observations for the years of the trial at Kadawa

\begin{tabular}{|c|c|c|c|c|c|c|c|c|c|c|c|c|c|}
\hline \multirow{2}{*}{ Parameter } & \multirow{2}{*}{ Year } & \multicolumn{12}{|c|}{ Month } \\
\hline & & Jan & Feb & Mar & Apr & May & Jun & Jul & Aug & Sep & Oct & Nov & Dec \\
\hline \multirow{3}{*}{ Rainfall (mm) } & 2009 & 0 & 0 & 0 & 0 & 12.2 & 116.8 & 247.3 & 224.7 & 139.7 & 6.5 & 0 & 0 \\
\hline & 2010 & 0 & 0 & 0 & 19.4 & 58.1 & 153.6 & 228.3 & 332.2 & 139.9 & 39.4 & 0 & 0 \\
\hline & 2011 & 0 & 0 & 0 & 23.2 & 7.2 & 111.6 & 150.0 & 170.3 & 116.9 & 11.5 & 0 & 0 \\
\hline \multicolumn{2}{|l|}{$\begin{array}{c}\text { Mean }(\mathrm{mm}) \\
\text { how many } \\
\text { years? }\end{array}$} & - & - & - & 14.2 & 25.8 & 127.3 & 208.5 & 242.4 & 132.2 & 19.1 & - & - \\
\hline \multirow{3}{*}{$\begin{array}{c}\text { Mean } \\
\text { Relative } \\
\text { Humidity (\%) }\end{array}$} & 2009 & 29.1 & 21.7 & 22.7 & 51.5 & 57.7 & 66.0 & 70.8 & 76.6 & 75.5 & 68.8 & 44.1 & 15.9 \\
\hline & 2010 & 36.3 & 27.4 & 40.0 & 58.9 & 69.9 & 76.9 & 75.9 & 71.6 & 68.1 & 28.9 & 19.8 & 13.3 \\
\hline & 2011 & 20.2 & 26.7 & 36.8 & 43.7 & 58.7 & 64.5 & 73.5 & 77.7 & 70.9 & 57.1 & 39.6 & 17.8 \\
\hline \multicolumn{14}{|c|}{ Mean Screen Temp. $\left({ }^{\circ} \mathrm{C}\right)$} \\
\hline \multirow{2}{*}{2009} & Max. & 33.3 & 36.0 & 38.3 & 41.8 & 39.4 & 37.0 & 32.9 & 32.1 & 33.3 & 35.5 & 32.8 & 18.4 \\
\hline & Min. & 15.9 & 18.2 & 21.5 & 26.0 & 24.7 & 23.7 & 23.1 & 23.2 & 23.7 & 19.2 & 16.1 & 15.3 \\
\hline \multirow{2}{*}{2010} & Max. & 32.5 & 36.9 & 37.9 & 40.6 & 39.9 & 35.2 & 31.2 & 31.2 & 32.2 & 34.9 & 35.5 & 25.6 \\
\hline & Min. & 14.8 & 19.2 & 22.3 & 26.2 & 26.5 & 24.3 & 23.0 & 22.3 & 22.2 & 22.4 & 18.0 & 16.1 \\
\hline \multirow{2}{*}{2011} & Max. & 32.1 & 36.3 & 39.5 & 40.1 & 39.6 & 34.7 & 32.1 & 30.7 & 33.3 & 34.7 & 35.0 & 31.3 \\
\hline & Min. & 16.0 & 20.0 & 21.5 & 23.5 & 25.9 & 23.8 & 22.6 & 21.5 & 22.3 & 21.9 & 19.3 & 18.4 \\
\hline \multirow{3}{*}{$\begin{array}{c}\text { Mean } \\
\text { Sunshine } \\
\text { (Hours/day) }\end{array}$} & 2009 & 10.1 & 10.5 & 10.0 & 7.0 & 7.7 & 8.3 & 8.1 & 6.3 & 7.4 & 7.8 & 9.1 & 10.5 \\
\hline & 2010 & 9.7 & 8.2 & 9.1 & 8.8 & 9.5 & 9.1 & 8.5 & 7.1 & 8.6 & 8.8 & 9.3 & 9.8 \\
\hline & 2011 & 8.1 & 8.2 & 9.1 & 8.8 & 9.5 & 9.1 & 8.5 & 7.1 & 8.6 & 8.8 & 9.4 & 9.1 \\
\hline \multirow{3}{*}{$\begin{array}{c}\text { Mean } \\
\text { Evaporation } \\
(\mathrm{mm} / \text { day })\end{array}$} & 2009 & 7.2 & 8.2 & 10.5 & 7.2 & 9.4 & 7.2 & 5.4 & 4.9 & 16.2 & 7.4 & 8.5 & 7.9 \\
\hline & 2010 & 8.7 & 9.3 & 13.1 & 93.2 & 10.1 & 7.2 & 8.2 & 5.8 & 8.0 & 6.3 & 7.3 & 8.4 \\
\hline & 2011 & 9.0 & 9.3 & 13.1 & 93.2 & 10.1 & 7.2 & 8.2 & 5.8 & 8.0 & 6.3 & 6.7 & 7.4 \\
\hline \multirow{3}{*}{$\begin{array}{l}\text { Mean Wind } \\
\text { run }(\mathrm{km} / \text { day })\end{array}$} & 2009 & 41.5 & 69.7 & 89.6 & 133.9 & 94.4 & 123.9 & 98.4 & 71.3 & 59.4 & 62.0 & 68.3 & 7.0 \\
\hline & 2010 & 57.9 & 67.3 & 94.7 & 93.1 & 124.6 & 101.2 & 97.8 & 72.5 & 61.3 & 60.5 & 69.2 & 3.0 \\
\hline & 2011 & 88.3 & 76.6 & 92.7 & 13.7 & 117.1 & 118.6 & 96.9 & 88.7 & 75.2 & 62.6 & 60.6 & 6.8 \\
\hline
\end{tabular}

Source: IAR Research Station, Kano (2012).

Table 2. Physical and chemical properties of soil samples obtained from Kadawa, Kano state during the 2009-2011 dry seasons

\begin{tabular}{llcl}
\hline \multirow{2}{*}{ Properties } & \multicolumn{3}{c}{ Soil depth (cm) } \\
\cline { 2 - 4 } & $0-20$ & $20-40$ & $40-60$ \\
\hline Physical composition (\%): & 11 & 11 & 9 \\
Clay & 20 & 18 & 20 \\
Silt & 69 & 71 & 71 \\
Sand & Silt-loam & Silt-loam & Silt-loam \\
Textural class & & & \\
Chemical composition: & 6.60 & 6.80 & 6.75 \\
pH $\left(\mathrm{H}_{2} \mathrm{O}\right)$ & 6.10 & 6.10 & 6.25 \\
pH $(0.01 \mathrm{~m} \mathrm{CaCl})$ & & & \\
\hline
\end{tabular}




\begin{tabular}{llll}
\hline Organic carbon $(\mathrm{g} / \mathrm{kg})$ & 0.77 & 0.57 & 0.24 \\
Available P (mg/kg) & 5.77 & 4.69 & 14.26 \\
Total N (\%) & 0.04 & 0.02 & 0.01 \\
Exchangeable bases: & & & \\
$\mathrm{Ca}^{++}$ & 2.00 & 2.80 & 2.00 \\
$\mathrm{Mg}^{++}$ & 1.20 & 1.60 & 1.10 \\
$\mathrm{~K}^{+}$ & 0.09 & 0.09 & 0.11 \\
$\mathrm{Na}^{+}$ & 0.50 & 0.70 & 0.87 \\
Exchangeable acidity: & & & \\
$\mathrm{H}-\mathrm{Al}(\mathrm{Cmol} / \mathrm{kg}$ soil) & 0.10 & 0.10 & 0.10 \\
\hline
\end{tabular}

\subsection{Experimental Details}

The experiment was laid out in a factorial design with two factors, ages of harvest of lablab $(6,9,12,15$ and 18 weeks after sowing, WAS) and irrigation schedules (3, 6 and 9 days intervals). The number of individual experimental units in each block was 15 . There were four replications, and the order of the experimental units in each replication was randomized. Individual plot size was $3 \mathrm{~m} \times 4.5 \mathrm{~m}$. Pre-seeding land preparation consisted of ploughing, harrowing and making of ridges. The site used for the trial was previously cropped with wheat (Triticum aestivum). Soil sampling was done in each plot at the depth of 0-20, 0-40 and 0-60 cm, respectively using soil auger and core sampler. The samples were randomly collected according to the procedures described by Blackman (1965). Lablab seeds were treated with seed dressing chemical (Apron Plus 50DS) at the recommended rate of $2 \mathrm{~g}$ to $2 \mathrm{~kg}$ of seeds (Adegbite et al., 2005). Maize (variety SAMAZ 14) and lablab (Rongai white variety) were sown at the same time by hand at a spacing of $30 \mathrm{~cm}$ within row between maize and lablab planted hills on ridges, which were $75 \mathrm{~cm}$ apart. Sowing was carried out in the middle of February in all the three years of the trial. Three (3) seeds were planted per hill for each crop and these were later thinned to two seedlings per hill at $3 \mathrm{WAS}$, to give a population of approximately 44,000 plants per ha per crop. In each trial year, the plots were weeded by hand at 3 and 6 WAS. The same amount of fertilizer $(120 \mathrm{~N}: 60 \mathrm{P}: 60 \mathrm{~K} \mathrm{~kg} / \mathrm{ha})$ was applied to all plots two days after the first weeding. Maize plants were top dressed with $60 \mathrm{Kg} / \mathrm{ha}$ in the form of urea $(46 \% \mathrm{~N})$ at 6 weeks after sowing. Uniform supplementary irrigation to root zone soil saturation (80 centibars for each irrigation treatment) was provided by flooding the soil surface using farmers' practice within the furrows at 3, 6 and 9 days interval from 2 weeks after sowing till physiological maturity stage for the maize (number of days from $50 \%$ plant emergence to when $50 \%$ of the cobs dried with leaf sheath turned brown) (Mahdi et al., 2011).

\subsection{Determination of Growth Parameters}

Data on growth parameters for maize and lablab (plant height, number of leaves and leaf area index (LAI) were taken at 6,9 and 12 WAS from five randomly selected plants from the two middle rows of each plot. Plant height was measured from the ground level to the tip of the flag leaf. Leaf area index was calculated as the ratio of leaf area to the area of ground cover at 6,9 and 12 WAS, respectively. Leaf area was calculated by multiplying the length of the leaf by its width and a factor of 0.75 as described by Adesoji et al. (2013).

\subsection{Estimation of Forage Yield of Lablab and Maize Grain Yield}

The forage dry matter $(\mathrm{DM})$ yield of lablab was estimated using $1.0 \mathrm{~m} \times 1.0 \mathrm{~m}$ quadrant. Plants within each quadrat were cut with hand sickle knife at $15 \mathrm{~cm}$ above ground level at 6, 9, 12, 15 and 18 WAS. The harvested fresh wet forage materials were weighed and a known weight of sub-samples (250-300 grams) was oven-dried at a temperature of $60{ }^{\circ} \mathrm{C}$ for $48 \mathrm{hrs}$ in a forced-draught oven. After drying, the sub-samples were re-weighed for estimation of DM yield. The samples were then milled to pass through a $1 \mathrm{~mm}$ sieve in preparation for laboratory analysis.

Maize grain yield per plot was determined from five randomly selected plants. At harvest, maize was at full physiological maturity stage. Cobs from the five maize plants were hand threshed. The extracted grain was weighed, dried and then re-weighed for estimation of grain yield. Cob length was determined using a meter rule while cob circumference was estimated using a thread and meter rule. 


\subsection{Chemical Analysis}

The milled forage samples of lablab were analyzed for proximate chemical composition using the procedures described by AOAC (2000). The components determined were the dry matter (DM), organic matter (OM), crude protein $(\mathrm{CP})$, crude fibre (CF), ether-extract (EE) and ash. Nitrogen free Extract (NFE) was determined by calculation $[\mathrm{NFE}=100-(\% \mathrm{CP}+\% \mathrm{CF}+\% \mathrm{EE}+\% \% \mathrm{Ash})]$. Organic matter was determined as $\% \mathrm{ODM}=100$ - \%ash, nitrogen was analyzed by the Kjeldahl method (AOAC, 2000) and crude protein calculated as \%Cp $=\% \mathrm{~N} * 6.25$, crude fibre was determined by means of Foss Tecator Analyzer, ether extract content-by Soxtec System 1040 and ash content of the samples was determined by igniting the samples in a muffle furnace at 550 ${ }^{\circ} \mathrm{C}$ for $8 \mathrm{~h}$. The resulting ash residue was digested in $6 \mathrm{M}$ nitric acid and the solution used for the determination of mineral components $(\mathrm{Ca}, \mathrm{Na}, \mathrm{P}, \mathrm{Mg}, \mathrm{Zn}, \mathrm{Fe}$, and $\mathrm{K}$ ) by an atomic absorption spectrophotometer according to standard laboratory methods (MAFF/ADAS, 1986) as briefly described by Shehu et al. (2001c). Acid detergent fibre (ADF) and Neutral detergent fibre (NDF) were analysed using the methods of Van Soest et al. (1991).

\subsection{Statistical Analyses}

Data compiled were subjected to analysis of variance using the General Linear Model (GLM) Procedure of Statistical Package for Social Scientists (SPSS, 2009). Age of harvest of lablab, irrigation frequency, year of trial and their interactions were used as fixed effects in the model. Age of harvest of lablab was considered as a repeated factor with the plots as subject of repeated measurements. Only main effects were considered on nutrient profile of lablab, maize grain yield, cob length and cob size because the interaction effects were not significant $(\mathrm{P}>0.05)$. Fisher's protected LSD tests were used to identify significant difference between means.

\section{Results}

\subsection{Yield Components of Maize/Lablab Mixtures}

Table 3 provides information on yield components of maize/lablab mixtures during the study period. Plant stand count and plant height of maize, as well as number of leaves of lablab were not affected $(\mathrm{P}>0.05)$ by years. But plant stand count of lablab, number of leaves of maize, plant height of lablab, and LAI of both maize and lablab significantly $(\mathrm{P}<0.05)$ varied with years. Plant stand count of lablab was higher in 2009 than 2010 and 2011. Number of leaves of maize and plant height of lablab appeared to be favoured in 2011 than other years. The LAI was respectively better for maize and lablab in 2011 and 2010. Age of plant affected $(\mathrm{P}<0.05)$ maize stand count, number of leaves of lablab and LAI of maize, as well as plant height of both maize and lablab. Only number of leaves of maize and lablab, and plant height of maize were not different $(P>0.05)$ with irrigation frequency. Plant stand count of maize and lablab, and plant height of lablab followed the same pattern with irriation frequency, all with greater values with 6-day irrigation frequency. The LAI was respectively highest for maize and lablab at 3- and 9-day irrigation frequency intervals.

Table 3. Effect of year of trial, age of plant and irrigation frequency on yield components of maize/lablab mixtures

\begin{tabular}{|c|c|c|c|c|c|c|c|c|}
\hline \multirow{2}{*}{$\begin{array}{l}\text { Treatment } \\
\text { Year }\end{array}$} & \multicolumn{2}{|c|}{$\underline{\text { Stand count }}$} & \multicolumn{2}{|c|}{ No. of leaves } & \multicolumn{2}{|c|}{ Plant height $(\mathrm{cm})$} & \multicolumn{2}{|c|}{$\underline{\text { Leaf Area Index }}$} \\
\hline & Maize & Lablab & Maize & Lablab & Maize & Lablab & Maize & Lablab \\
\hline 2009 & 42.42 & $23.58^{\mathrm{a}}$ & $19.48^{\mathrm{b}}$ & 22.30 & 88.03 & $111.33^{\mathrm{c}}$ & $2.35^{b}$ & $\begin{array}{l}0.45^{\mathrm{b}} \\
0.95^{\mathrm{a}}\end{array}$ \\
\hline 2010 & 40.42 & $16.33^{b}$ & $11.92^{\mathrm{c}}$ & 20.98 & 96.05 & $137.90^{\mathrm{b}}$ & $2.50^{\mathrm{b}}$ & $0.95^{\mathrm{a}}$ \\
\hline 2011 & 39.58 & $18.33^{\mathrm{b}}$ & $27.45^{\mathrm{a}}$ & 22.50 & 93.36 & $160.58^{\mathrm{a}}$ & $2.75^{\mathrm{a}}$ & $0.35^{\mathrm{b}}$ \\
\hline LSD & 7.65 & 3.25 & 5.02 & 2.33 & 12.47 & 18.88 & 0.22 & 0.25 \\
\hline Significance & NS & $*$ & $*$ & NS & NS & * & * & * \\
\hline Age of plant & & & & & & & & \\
\hline 6 & $37.25^{\mathrm{b}}$ & 19.25 & 17.98 & $17.25^{\mathrm{b}}$ & $26.48^{\mathrm{c}}$ & $34.04^{c}$ & $1.6^{\mathrm{b}}$ & $0.6^{\mathrm{a}}$ \\
\hline 9 & $47.50^{\mathrm{a}}$ & 18.42 & 19.95 & $25.78^{\mathrm{a}}$ & $89.32^{\mathrm{b}}$ & $145.74^{\mathrm{b}}$ & $3^{\mathrm{a}}$ & $0.5^{\mathrm{b}}$ \\
\hline 12 & $37.67^{\mathrm{b}}$ & 20.58 & 20.92 & $22.75^{\mathrm{a}}$ & $161.64^{\mathrm{a}}$ & $230.03^{\mathrm{a}}$ & $3^{\mathrm{a}}$ & $0.6^{\mathrm{a}}$ \\
\hline LSD & 7.11 & 2.98 & 6.22 & 7.77 & 25.55 & 29.99 & 1.00 & 0.07 \\
\hline LOS & * & NS & NS & * & * & * & * & NS \\
\hline
\end{tabular}




\begin{tabular}{lcccccccc}
\hline Irrigation frequency (days) & & & & & & & & \\
3 & $36.09^{\mathrm{b}}$ & $18.45^{\mathrm{b}}$ & 17.85 & 21.79 & 88.51 & $120.52^{\mathrm{b}}$ & $3.15^{\mathrm{a}}$ & $0.4^{\mathrm{b}}$ \\
6 & $46.47^{\mathrm{a}}$ & $22.00^{\mathrm{a}}$ & 11.25 & 22.15 & 100.38 & $160.04^{\mathrm{a}}$ & $2.05^{\mathrm{c}}$ & $0.4^{\mathrm{b}}$ \\
9 & $37.50^{\mathrm{b}}$ & $16.60^{\mathrm{b}}$ & 12.10 & 21.74 & 85.00 & $119.15^{\mathrm{b}}$ & $2.55^{\mathrm{b}}$ & $1.05^{\mathrm{a}}$ \\
LSD & 8.71 & 3.33 & 10.01 & 6.47 & 21.11 & 25.00 & 0.42 & 0.39 \\
Significance & $*$ & $*$ & NS & NS & NS & $*$ & $*$ & $*$
\end{tabular}

${ }_{a b c}$ Means with different superscripts within columns differed significantly $(\mathrm{P}<0.05)$, LAI $=$ Leaf Area Index, WAS $=$ Weeks After Sowing, LSD = Least Significant Difference between two pairs of Means, NS = Not Significant $(\mathrm{P}>0.05)$.

\subsection{Forage Yield of Lablab}

Table 4 shows both wet and dry forage yields of lablab as affected by year $\times$ age of cutting interaction. For both wet and dry yields, there were significant $(\mathrm{P}<0.05)$ year $\mathrm{x}$ age of cutting interaction. In 2010 and 2011 , wet forage yields were higher at 18 WAS compared to 2009. A similar trend was observed in dry forage yield. However, both wet and dry forage yields were higher in 2009 at 15 WAS compared to other years.

Table 4. Effect of age of cutting on forage yield of lablab as influenced by year of trial

\begin{tabular}{llllllll}
\hline & \multicolumn{3}{l}{ Fresh forage yield (t/ha) } & & \multicolumn{3}{c}{ Dry matter yield (t/ha) } \\
\cline { 2 - 3 } \cline { 7 - 8 } Age of cutting & 2009 & 2010 & 2011 & & 2009 & 2010 & 2011 \\
\hline 6 weeks & $5.50^{\mathrm{b}}$ & $7.29^{\mathrm{a}}$ & $6.58^{\mathrm{d}}$ & & $4.31^{\mathrm{c}}$ & $4.21^{\mathrm{c}}$ & $5.03^{\mathrm{c}}$ \\
9 weeks & $6.81^{\mathrm{a}}$ & $6.17^{\mathrm{c}}$ & $7.91^{\mathrm{c}}$ & & $5.13^{\mathrm{b}}$ & $5.44^{\mathrm{b}}$ & $5.73^{\mathrm{b}}$ \\
12 weeks & $4.59^{\mathrm{c}}$ & $4.24^{\mathrm{d}}$ & $6.27^{\mathrm{d}}$ & & $3.51^{\mathrm{d}}$ & $3.68^{\mathrm{c}}$ & $4.57^{\mathrm{d}}$ \\
15 weeks & $7.29^{\mathrm{a}}$ & $6.87^{\mathrm{b}}$ & $8.86^{\mathrm{b}}$ & & $5.94^{\mathrm{a}}$ & $5.25^{\mathrm{b}}$ & $5.97^{\mathrm{b}}$ \\
18 weeks & $4.48^{\mathrm{c}}$ & $7.33^{\mathrm{a}}$ & $9.44^{\mathrm{a}}$ & & $3.59^{\mathrm{d}}$ & $6.08^{\mathrm{a}}$ & $7.22^{\mathrm{a}}$ \\
LSD & 0.81 & 0.28 & 0.34 & & 0.63 & 0.72 & 0.63 \\
Significance & $*$ & $*$ & $*$ & & $*$ & $*$ & $*$
\end{tabular}

${ }^{\mathrm{abc}}$ Means with different superscripts within columns differed significantly $(\mathrm{P}<0.05)$, LSD $=$ Least Significant Difference between two pairs of Means.

Table 5 shows both wet and dry forage yield of lablab as influenced by irrigation schedule $\mathrm{x}$ age of cutting. Interactions between irrigation schedule $\mathrm{x}$ age of cutting were significant $(\mathrm{P}<0.05)$. At 12 WAS, the fresh forage yield showed an increasing trend at irrigation interval of 3 days, but further increase in irrigation interval to 6 days, produced higher forage yield at 9 WAS. However, at 9-days irrigation interval, there was $12 \%$ decrease in forage yield at $18 \mathrm{WAS}$ compared to $12 \mathrm{WAS}$. The dry forage yield showed $17 \%$ decrease at $18 \mathrm{WAS}$ when the irrigation interval was increased to 9-days. Dry forage yields at 3 and 6-days irrigation intervals were at par at 18WAS. Generally, both fresh and dry forage yield increased with age of cutting at depending on the irrigation frequency. 
Table 5. Effect of age of cutting on forage yield of lablab as influenced by irrigation frequency

\begin{tabular}{lcccccc}
\hline & \multicolumn{5}{c}{ Irrigation frequency (days) } \\
\cline { 2 - 7 } Age of cutting & 3 & 6 & 9 & 3 & 6 & 9 \\
& \multicolumn{5}{c}{ Fresh forage yield (t/ha) } & \multicolumn{3}{c}{ Dry matter yield (t/ha) } \\
\hline 6 weeks & $5.94^{\mathrm{b}}$ & $5.99^{\mathrm{b}}$ & $6.73^{\mathrm{c}}$ & $5.00^{\mathrm{c}}$ & $4.96^{\mathrm{c}}$ & $4.94^{\mathrm{b}}$ \\
9 weeks & $5.67^{\mathrm{c}}$ & $6.26^{\mathrm{ab}}$ & $6.82^{\mathrm{c}}$ & $4.97^{\mathrm{c}}$ & $4.99^{\mathrm{c}}$ & $4.96^{\mathrm{b}}$ \\
12 weeks & $6.90^{\mathrm{a}}$ & $7.36^{\mathrm{a}}$ & $7.60^{\mathrm{a}}$ & $5.60^{\mathrm{b}}$ & $5.99^{\mathrm{b}}$ & $6.02^{\mathrm{a}}$ \\
15 weeks & $6.87^{\mathrm{a}}$ & $6.65^{\mathrm{a}}$ & $7.22^{\mathrm{b}}$ & $4.94^{\mathrm{c}}$ & $5.01^{\mathrm{c}}$ & $6.01^{\mathrm{a}}$ \\
18 weeks & $7.15^{\mathrm{a}}$ & $7.15^{\mathrm{a}}$ & $6.80^{\mathrm{c}}$ & $6.07^{\mathrm{a}}$ & $6.56^{\mathrm{a}}$ & $4.97^{\mathrm{b}}$ \\
LSD & 0.24 & 0.63 & 0.30 & 0.40 & $0.37^{\circ}$ & 0.61 \\
Significance & $*$ & $*$ & $*$ & $*$ & $*$ & $*$
\end{tabular}

abc Means with different superscripts within columns differed significantly $(\mathrm{P}<0.05)$, LSD $=$ Least Significant Difference between two pairs of Means .

There were significant $(\mathrm{P}<0.05)$ interaction effects between irrigation schedule $\times$ year of trial on both fresh and dry forage yield (Table 6). Both fresh and dry forage yield showed decreasing trend at irrigation interval of 9 days with highest values recorded in 2009. Irrigation interval of 3days produced higher fresh and dry forage yield in 2010. In 2011, the dry forage yield was $4 \%$ higher at irrigation interval of 6-days.

Table 6. Effect of year of trial on forage yield of lablab as influenced by irrigation frequency

\begin{tabular}{|c|c|c|c|c|c|c|}
\hline \multirow{3}{*}{ Age of cutting } & \multicolumn{6}{|c|}{ Irrigation frequency (days) } \\
\hline & 3 & 6 & 9 & 3 & 6 & 9 \\
\hline & \multicolumn{3}{|c|}{ Fresh forage yield (t/ha) } & \multicolumn{3}{|c|}{ Dry matter yield (t/ha) } \\
\hline 2009 & $6.60^{b}$ & $6.87^{\mathrm{c}}$ & $7.73^{\mathrm{a}}$ & $4.40^{b}$ & $3.85^{\mathrm{c}}$ & $4.12^{a}$ \\
\hline 2010 & $7.11^{\mathrm{a}}$ & $9.00^{\mathrm{a}}$ & $6.33^{b}$ & $4.82^{\mathrm{a}}$ & $5.01^{\mathrm{b}}$ & $3.93^{b}$ \\
\hline 2011 & $5.55^{\mathrm{c}}$ & $8.41^{\mathrm{b}}$ & $5.47^{\mathrm{c}}$ & $3.67^{\mathrm{c}}$ & $5.23^{\mathrm{a}}$ & $3.77^{c}$ \\
\hline LSD & 0.10 & 0.22 & 0.51 & 0.19 & 0.16 & 0.11 \\
\hline Significance & $*$ & $*$ & $*$ & $*$ & $*$ & $*$ \\
\hline
\end{tabular}

${ }^{a b c}$ Means with different superscripts within Columns differed significantly $(\mathrm{P}<0.05)$, LSD $=$ Least Significant Difference.

Table 7 shows significant $(\mathrm{P}<0.05)$ interaction effects between age of cutting $\mathrm{x}$ year of trial $\mathrm{x}$ irrigation schedule on dry forage yield of lablab. In 2009 and 2011, there was a significant increasing trend in dry forage yield from $6 \mathrm{WAS}$ until $15 \mathrm{WAS}$, where it slightly decreased by $5 \%$ at $18 \mathrm{WAS}$, however, dry forage yield of lablab decreased by $15 \%$ at 18 WAS in 2010 . Irrigation interval of 3-days produced the highest forage yield at $15 \mathrm{WAS}$, but the forage yield decreased by about $10 \%$ when the irrigation interval was increased to 6-days. Furthermore, increasing the number of days to irrigation (from 6-to-9 days), led to $1 \%$ decrease in forage yield at $12 \mathrm{WAS}$ compared to 3-days irrigation interval, respectively. 
Table 7. Effect of year of trial and irrigation frequency on dry matter yield of lablab (t/ha) at different ages of cutting

\begin{tabular}{llllllll}
\hline $\begin{array}{l}\text { Age of cutting (WAS) } \\
\text { Year }\end{array}$ & 6 & 9 & 12 & 15 & 18 & LSD & LOS \\
\hline 2009 & $5.50^{\mathrm{d}}$ & $6.81^{\mathrm{c}}$ & $5.59^{\mathrm{d}}$ & $7.29^{\mathrm{b}}$ & $7.48^{\mathrm{a}}$ & 0.17 & $*$ \\
2010 & $7.29^{\mathrm{a}}$ & $6.17^{\mathrm{b}}$ & $4.25^{\mathrm{c}}$ & $5.87^{\mathrm{b}}$ & $6.34^{\mathrm{b}}$ & 0.53 & $*$ \\
2011 & $6.58^{\mathrm{d}}$ & $7.91^{\mathrm{c}}$ & $6.27^{\mathrm{e}}$ & $8.86^{\mathrm{a}}$ & $8.44^{\mathrm{b}}$ & 0.29 & $*$ \\
Irrigation frequency (days) & & & & & & & \\
3 days & $4.03^{\mathrm{d}}$ & $4.92^{\mathrm{c}}$ & $5.08^{\mathrm{c}}$ & $8.43^{\mathrm{a}}$ & $8.11^{\mathrm{b}}$ & 0.27 & $*$ \\
6 days & $4.73^{\mathrm{d}}$ & $5.66^{\mathrm{c}}$ & $7.00^{\mathrm{b}}$ & $6.46^{\mathrm{b}}$ & $7.70^{\mathrm{a}}$ & 0.60 & $*$ \\
9 days & $5.38^{\mathrm{c}}$ & $4.62^{\mathrm{d}}$ & $8.33^{\mathrm{a}}$ & $7.12^{\mathrm{b}}$ & $5.45^{\mathrm{c}}$ & 0.74 & $*$ \\
\hline
\end{tabular}

${ }^{a b c}$ Means with different superscripts within rows differed significantly $(\mathrm{P}<0.05)$, WAS = Weeks After Sowing, $\mathrm{SLD}=$ Least Significant Difference between two pairs of Means, LOS $=$ Level of Significance.

\subsection{Nutrient Profile of Lablab}

Table 8 shows the nutrient profile of lablab forage as affected by age of cutting, irrigation frequency and year of trial. Age of cutting had no effect $(\mathrm{P}>0.05)$ on forage $\mathrm{Mg}$ and $\mathrm{Na}$ contents of lablab. The $\mathrm{CP}$ contents of lablab at 15 and 18 WAS were lower significantly than the CP at 6 WAS. The forage CF, NDF and ADF Sort of followed similar pattern with advancing age of lablab. Earlier harvests appeared to have lower CF, NDF and $\mathrm{ADF}$ values than later harvests. Both EE and NFE followed similar pattern and they both decreased as the age of lablab increased. The forage Ca content was significantly lower at 15 WAS than other harvest dates. The forage $\mathrm{P}$ was significantly lower at 18 WAS than all earlier harvest dates. The resulting Ca: $\mathrm{P}$ ratios were significantly lowest at 6 WAS (0.66) and highest at 18 WAS (1.35). With the exception of ADF and Ca: P, all measured nutrient indicators in the present study did not differ $(\mathrm{P}>0.05)$ with irrigation frequency (Table 8). The forage ADF was significantly lower for 6-day irrigation interval than 3 and 9 days. For Ca: $\mathrm{P}$ the order was: 6-day > 9-day > 3-day. The NDF, ADF, EE, NFE, P and Na of lablab forage were significantly higher in 2009 than in other years of the trial. In 2010, there were better CP, CF, EE, Ca, Mg and Ca: P values than in other years. Lower values of nutrient composition of lablab were however observed in 2011 except in ADF and Na.

Table 8. Effect of age of cutting, irrigation frequency and year of trial on nutrient composition of lablab forage

\begin{tabular}{|c|c|c|c|c|c|c|c|c|c|c|c|c|}
\hline \multirow[b]{2}{*}{ Age of cutting (WAS) } & \multicolumn{12}{|c|}{ Nutrient composition (\%) } \\
\hline & $\mathrm{CP}$ & $\mathrm{CF}$ & NDF & $\mathrm{ADF}$ & $\mathrm{EE}$ & NFE & $\mathrm{ASH}$ & $\mathrm{Ca}$ & $\mathrm{P}$ & $\mathrm{Mg}$ & $\mathrm{Na}$ & $\mathrm{Ca}: \mathrm{P}$ \\
\hline 6 & $17.17^{\mathrm{a}}$ & $11.52^{b}$ & $53.62^{b}$ & $17.13^{b}$ & $0.74^{\mathrm{a}}$ & $55.85^{\mathrm{a}}$ & 9.50 & $0.90^{\mathrm{b}}$ & $1.36^{\mathrm{a}}$ & 0.78 & 0.80 & $0.66^{\mathrm{d}}$ \\
\hline 9 & $15.63^{a b}$ & $12.15^{b}$ & $54.56^{\mathrm{b}}$ & $21.79^{\mathrm{a}}$ & $0.55^{\mathrm{a}}$ & $54.11^{\mathrm{a}}$ & 9.53 & $1.11^{\mathrm{a}}$ & $1.22^{\mathrm{a}}$ & 0.77 & 0.76 & $0.91^{b}$ \\
\hline 12 & $13.45^{\mathrm{ab}}$ & $14.25^{\mathrm{ab}}$ & $58.48^{\mathrm{a}}$ & $21.26^{\mathrm{a}}$ & $0.46^{\mathrm{ab}}$ & $52.69^{a b}$ & 8.47 & $0.86^{\mathrm{c}}$ & $1.20^{\mathrm{a}}$ & 0.62 & 0.74 & $0.72^{\mathrm{c}}$ \\
\hline 15 & $11.23^{b}$ & $19.61^{\mathrm{a}}$ & $58.44^{\mathrm{a}}$ & $19.92^{\mathrm{a}}$ & $0.41^{\mathrm{b}}$ & $51.41^{b}$ & 9.11 & $0.73^{c}$ & $1.04^{\mathrm{ab}}$ & 0.76 & 0.75 & $0.70^{\mathrm{c}}$ \\
\hline 18 & $10.07^{b}$ & $18.89^{\mathrm{a}}$ & $59.70^{\mathrm{a}}$ & $20.63^{\mathrm{a}}$ & $0.35^{b}$ & $51.32^{b}$ & 9.16 & $1.11^{\mathrm{a}}$ & $0.82^{b}$ & 0.68 & 0.70 & $1.35^{\mathrm{a}}$ \\
\hline LSD & 4.11 & 5.55 & 3.72 & 2.80 & 0.22 & 3.33 & 2.89 & 0.19 & 0.30 & 0.41 & 0.27 & 0.16 \\
\hline Significance & $*$ & $*$ & $*$ & $*$ & $*$ & $*$ & NS & $*$ & $*$ & NS & NS & $*$ \\
\hline \multicolumn{13}{|c|}{ Irrigation frequency (days) } \\
\hline 3 & 14.68 & 16.25 & 57.45 & $20.22^{b}$ & 0.66 & 55.64 & 9.48 & 0.86 & 1.09 & 0.64 & 0.80 & $0.79^{c}$ \\
\hline 6 & 15.05 & 17.03 & 55.06 & $19.39^{b}$ & 0.70 & 54.11 & 8.95 & 0.94 & 1.08 & 0.79 & 0.74 & $0.87^{\mathrm{a}}$ \\
\hline 9 & 16.03 & 14.90 & 59.31 & $22.58^{\mathrm{a}}$ & 0.90 & 55.49 & 9.10 & 1.03 & 1.24 & 0.72 & 0.70 & $0.83^{b}$ \\
\hline LSD & 2.99 & 3.01 & 2.68 & 2.32 & 0.35 & 2.23 & 2.46 & 2.73 & 2.54 & 1.99 & 1.16 & 0.02 \\
\hline Significance & NS & NS & NS & $*$ & NS & NS & NS & NS & NS & NS & NS & $*$ \\
\hline Year of trial & & & & & & & & & & & & \\
\hline
\end{tabular}




\begin{tabular}{lllllllllllll}
\hline 2009 & $13.90^{\mathrm{c}}$ & $15.69^{\mathrm{c}}$ & $58.24^{\mathrm{a}}$ & $21.46^{\mathrm{a}}$ & $0.92^{\mathrm{a}}$ & $59.42^{\mathrm{a}}$ & $9.43^{\mathrm{a}}$ & $0.81^{\mathrm{c}}$ & $1.32^{\mathrm{a}}$ & $0.60^{\mathrm{b}}$ & $0.79^{\mathrm{a}}$ & $0.61^{\mathrm{c}}$ \\
2010 & $15.33^{\mathrm{a}}$ & $16.72^{\mathrm{a}}$ & $56.79^{\mathrm{c}}$ & $19.18^{\mathrm{b}}$ & $0.94^{\mathrm{a}}$ & $52.49^{\mathrm{c}}$ & $9.01^{\mathrm{c}}$ & $0.88^{\mathrm{a}}$ & $0.89^{\mathrm{c}}$ & $0.62^{\mathrm{a}}$ & $0.72^{\mathrm{b}}$ & $1.00^{\mathrm{a}}$ \\
2011 & $14.68^{\mathrm{b}}$ & $15.99^{\mathrm{b}}$ & $57.00^{\mathrm{b}}$ & $21.88^{\mathrm{a}}$ & $0.63^{\mathrm{b}}$ & $55.64^{\mathrm{b}}$ & $9.19^{\mathrm{b}}$ & $0.83^{\mathrm{b}}$ & $1.05^{\mathrm{b}}$ & $0.58^{\mathrm{c}}$ & $0.77^{\mathrm{a}}$ & $0.80^{\mathrm{b}}$ \\
LSD & 0.50 & 0.10 & 0.08 & 1.11 & 0.10 & 2.40 & 0.13 & 0.01 & 0.08 & 0.01 & 0.03 & 0.09 \\
Significance & $*$ & $*$ & $*$ & $*$ & $*$ & $*$ & $*$ & $*$ & $*$ & $*$ & $*$ & $*$
\end{tabular}

${ }_{\mathrm{abc}}$ Means with different superscripts within columns differed significantly $(\mathrm{P}<0.05)$, WAS $=$ Weeks After Sowing, LSD $=$ Least Significant Difference between two pairs of Means, NS = Not Significant $(P>0.05)$.

\subsection{Yield Components of Maize}

Results of yield components of maize as influenced by year of trial and irrigation frequency are presented in Table 9. The maize grain yield was higher significantly $(\mathrm{P}<0.05)$ in both 2010 and $2011(1722-1726 \mathrm{~kg} / \mathrm{ha})$ than $20091412 \mathrm{~kg} / \mathrm{ha})$. The maize cob length was lower significantly $(\mathrm{P}<0.05)$ in 2010 than $2009(12.89 \mathrm{~cm})$ and $2011(13.34 \mathrm{~cm})$. The maize cob size was not affected $(\mathrm{P}>0.05)$ by year of trial. Only maize cob length was not affected $(\mathrm{P}>0.05)$ by irrigation frequency (Table 9). Both maize grain yield and cob size followed the same order with irrigation frequency: 3 -day $>6$-day $>9$-day.

Table 9. Effect of year of trial, irrigation frequency and their interaction on yield components of maize

\begin{tabular}{lccc}
\hline & \multicolumn{3}{c}{ Yield parameters } \\
\cline { 2 - 4 } Year of trial & Grain yield (kg/ha) & Cob length (cm) & Cob circumference (cm) \\
\hline 2009 & $1412^{\mathrm{b}}$ & $12.89^{\mathrm{a}}$ & 8.97 \\
2010 & $1726^{\mathrm{a}}$ & $12.00^{\mathrm{b}}$ & 9.05 \\
2011 & $1722^{\mathrm{a}}$ & $13.34^{\mathrm{a}}$ & 9.12 \\
LSD & 176 & 0.47 & 0.43 \\
Significance & $*$ & $*$ & $\mathrm{NS}$ \\
Irrigation frequency (days) & & & \\
3 days & $1937^{\mathrm{a}}$ & 13.11 & $9.56^{\mathrm{a}}$ \\
6 days & $1609^{\mathrm{b}}$ & 12.61 & $9.04^{\mathrm{b}}$ \\
9 days & $1274^{\mathrm{c}}$ & 12.74 & $8.28^{\mathrm{c}}$ \\
LSD & $188^{\mathrm{a}}$ & 0.61 & 0.26 \\
Significance & $*$ & $\mathrm{NS}$ & $*$ \\
Interaction & & & $*$ \\
Y $\times$ I & $\mathrm{NS}$ & $\mathrm{NS}$ &
\end{tabular}

abc Means with different superscripts within columns differed significantly $(\mathrm{P}<0.05)$, LSD $=$ Least Significant Difference between two pairs of Means, NS = Not Significant $(\mathrm{P}>0.05), \mathrm{Y} \times \mathrm{I}=$ Interaction between Year of trial and Irrigation interval.

\section{Discussion}

\subsection{Forage Yield of Lablab}

The productivity of lablab plants depends on solar radiation which provides the energy necessary for photosynthetic processes (Akanvou, 2001). Lablab plants had greater opportunity for access to light as a result of twinning of maize plants in mixtures (Ngongoni et al., 2007). The significant differences in both fresh and dry matter yield of lablab (Tables 4, 5 and 6) can be explained by the competitive ability of lablab in mixtures which was facilitated by the optimum temperature as at the time of the trial since growth of most legumes had been reported to be positively correlated with temperature (Akanvou, 2001). Lablab produces encouraging fresh (38.60-50.50 t/ha) and dry (12.47-22.24 t/ha) forage yield in mixtures under irrigation (Muna et al., 2011; Abusuwar \& Al-Solimani, 2013), provided the soil moisture content is not excessive (Aganga \& Tshwenyane, 
2003). The values observed in this study falls within the range of 5-14 t/ha reported to be adequate for good forage legume (Onifade et al., 1998; Mokoboki et al., 2002). The dry matter yield of lablab observed in this study was however higher than the values of 1.4 to $7.07 \mathrm{t} / \mathrm{ha}$ reported in previous studies (Omokanye et al., 1996; Onifade et al., 1998; Agyemang et al., 2000; Omokanye et al., 2004; Amodu et al., 2004; Anthony \& John, 2007) This indicates that lablab can be successfully incorporated into maize stand under irrigation, despite the fact that the smallholder farmers do not consider growing lablab under irrigation as a viable option for improving livelihoods. However, the values recorded in this study were lower than the values of $13 \mathrm{t} / \mathrm{ha}, 8 \mathrm{t} / \mathrm{ha}$ and $14.8 \mathrm{t} / \mathrm{ha}$ for lablab under rain-fed condition (Shehu et al., 2001; Mokoboki et al., 2002; John, 2006). This might be related to differences in geographical location, date of sowing, initial stand counts, soil type and competitive ability of lablab.

The trend in dry matter yield in this study was similar to the findings of Omokanye et al. (1996) that at maturity the proportion of stem increases in legumes at the expense of leaves as a result of increased formation of lignified structures. The significant interaction between year of trial and irrigation interval (Table 6), indicates that dry matter yield of lablab fluctuates based on prevailing environmental conditions within the year and the level of moisture in the soil. Therefore, farmers should plan their production activities based on available information from the national weather forecast stations due to the present change in global climate. This indicates that provided the environmental temperature is adequate $\left(18-30{ }^{\circ} \mathrm{C}\right)$ and irrigation interval does not go beyond 3 days; lablab will continue to grow due to decreased leaf senescence and increased elongation of stems. This will offer greater advantage to the smallholder farmers in Nigeria in terms of land equivalent ratio (LER) and continued supply of fresh and qualitative forage to livestock. Also, farmers could receive additional income from the sale of lablab forage to the Fulani herdsmen, who are known to reside near areas with irrigation facilities.

\subsection{Yield Components of Maize/Lablab Mixtures}

This study was conducted to evaluate the possibility of integrating maize/lablab mixtures into the dry season farming system in Nigeria. In this study, the stand count of lablab was consistently lower than that of maize in all the years of the trial (Table 3). This was mainly due to seed rotting and the damage caused on lablab seed by birds, rodents and insects, days following seeding. Rashid (2010) reported a similar observation in maize-mungbean mixtures in Pakistan. The stand count values recorded for lablab in this study were comparable to the findings of Malami and Sama'ila (2012) in cowpea (Vigna unguiculata (L.) Walp. Var. Kanannado). The values for number of leaves of lablab observed in this study (19, 12 and 27) were higher than the values $(12,13$ and 14) reported under rain-fed condition in Samaru at 6, 9 and 12 weeks after sowing (Adesoji et al., 2013). The value observed in plant height of lablab in the third year $(161 \mathrm{~cm})$ was however higher than the value $(150 \mathrm{~cm})$ observed by Yusufali (2005) in India and Omokanye et al. (2000) but lower than the value $(229 \mathrm{~cm})$ observed in Samaru (Adesoji et al., 2013). The high LAI in maize in this study can be ascribed to better leaf growth possibly due to good soil moisture and environmental temperature and vertical plant architecture, which might have offered advantage over lablab which grows horizontally. Mohankumar et al. (2012) observed higher LAI (4.55) in maize when intercropped with lablab in $4: 2$ row proportions with $100 \%$ NPK in India. The tendency for shading (i.e. covering the leaf from sunlight) between the mixtures was evidenced in the thinner leaves observed in lablab due to continuous cover provided by the maize plants due to their upright nature. This partly explains the low LAI observed in lablab compared to maize. However, our values for stand count were lower than the value of 42 plants $/ \mathrm{m}^{2}$ recorded by Omokanye et al. (2000) for Horsegram (Macrotyloma uniflorum) at Shika.

\subsection{Maize Grain Yield}

Intercropping maize with forage legumes had been reported to decrease maize grain yields (Gbarennah et al., 2004; Mkamilo, 2004). The maize grain yield recorded in this study (Table 9) was below the potential maize yield of 7 metric tons per ha earlier reported (IITA, 2011). The reason for this might be related to differences in measured yield components of maize (cob length, cob circumference, number of cobs per plant and cob weight) and the competitive ability of the species since lablab has been reported to compete favourably well with other species in mixtures (Ngongoni et al., 2007; Birteeb et al., 2011). This is evidenced in plant height of lablab plant which was consistently higher than that of maize plant (Table 3). The current maize yield reported from smallholder farmers in Nigeria is 1.4-1.5t/ha (IITA, 2011). Since irrigating at 3 days interval produced the highest maize grain yield (1.9 $\mathrm{t} / \mathrm{ha}$ ), it implies that smallholder farmers in Nigeria could practice food-forage technology under irrigation without adverse effect on maize grain yield. Another major advantage to be derived from such cropping mixtures is increased nutrients availability in the soil (Birteeb et al., 2011) which could be utilized by the succeeding cereal crop in subsequent cropping seasons and improved efficiency in terms of land equivalent ratio (Rashid, 2010). 


\subsection{Nutrient Composition of Lablab}

Age of cutting, irrigation frequency and year of trial affected the nutrient composition of Lablab (Table 8). The range (10.1- 17.2) of crude protein (CP) content obtained in this study fall within the range reported for tropical herbaceous legumes (Murphy \& Colucci, 1999; Mpairwe et al., 2003; Kabirizi, 2006; Mupangwa et al., 2006; Abia, 2011). The $\mathrm{CP}$ values observed in this study met the requirements of growing goats (10-31\% CP) (Alemu, 2008) and lambs $(9.1-15.1 \% \mathrm{CP})(\mathrm{NRC}, 1985)$. Nitrogen requirements of ruminant livestock had been reported to range from 1.2-2.7\% (NRC, 1985). The crude protein values observed in this study could satisfactorily supply the required nitrogen for ruminant livestock. The sharp decrease in the crude protein content of lablab at 9 weeks of age might be due to the nitrogen fertilizer applied to maize plants since fertilizer application in mixed pastures had been reported to decrease the quality of the legume component (Ball et al., 2001). This therefore explains the trend in the crude fibre content which was found to increase with advancing plant age.

The crude fibre content of lablab in this study was lower than the value of $24-32 \%$ reported in earlier studies (Murphy \& Colucci, 1999). This might be due to the low temperature observed during the early (January February) establishment period in the three years of the trial. Anthony and John (2007) had shown that temperature affects the crude fibre content of tropical leguminous forages. In this study, the values for calcium ranged from $0.73-1.11 \%$. These values can satisfactorily meet the daily calcium requirements of goats which require $0.5-1.1 \mathrm{~g}$ of calcium per day (Alemu, 2008). The calcium requirement for young cattle had been reported to be $3.5 \%$ (NRC, 1985). This indicates that in addition to lablab forage, farmers need to supplement calcium to their young steers especially during the dry season for better performance. The values observed in this study were however lower than the reported values of 1.67 and $1.86 \%$ found in temperate forage legumes (Abia, 2011). The values of phosphorus recorded in this study were substantially higher than the reported literature values of $0.76 \%$ and $0.88 \%$, respectively (Nworgu \& Ajayi, 2005; Abia, 2011). This can be explained by the ability of lablab plant to profusely nodulate and grow well on the sandy soil of Kadawa which had been known to contain moderate range (4.69-14.26 $\mathrm{mg} / \mathrm{kg}$ ) of phosphorus (Oyinlola \& Chude, 2011). The decreasing trend of phosphorus level observed in this study with increase in age of cutting is in agreement with the report of Abia (2011) that phosphorus concentration in herbage decreases with increase in maturity. The phosphorus level recorded in this study $(0.8-1.4 \%)$ was enough to supply the requirements of goats $(0.4-0.9 \mathrm{~g} /$ day $)$, sheep $(0.2-0.3 \%)$, replacement heifers (0.3\%-1\%) (Hubbard Feeds, 2014), lactating cows (0.4\%) and steers (0.2\%) (Ron, 2005; Alemu, 2008; NRC, 1985). The high phosphorus content of lablab forage in this study is an advantage to the smallholder farmers since phosphorus is needed by the rumen bacteria for efficient digestion of fibrous materials (Dierenfeld et al., 2014). Therefore, the food-forage technology tested in this study will assist the smallholder farmers improve the performance of their livestock and hence improve their income and livelihoods.

\subsection{Benefits for Smallholder Farmers}

This study will help the smallholder farmers to overcome issues militating against high productivity of crops and livestock during the dry season period in Nigeria. The use of ley legumes as technology to address feed shortage in livestock and environmental degradation has since been recognized (Mapiye et al., 2007). In Nigeria, the quantity of fertilizer required by cereal crops will be low when they are produced in mixtures with forage legumes such as lablab under irrigation. Both farmers and their families will attain improved livelihoods through extra income and food security from maize/lablab mixtures under irrigation. Similarly, the smallholder mixed crop-livestock system will be more sustainable in the future by providing high quality feed to livestock in the form of silage, hay and pelleted feeds for ruminant livestock. Also, the soil health will improve due to low use of expensive chemical fertilizers by farmers.

\section{Conclusion}

This study reveals that lablab forage could be incorporated into the present conventional irrigated cereal based system, for optimum profitability and less environmental destructions in Nigeria. Harvesting lablab forage at the age of 15 weeks will produce the highest dry matter yield which can be used for ensiling or as hay. Delaying the harvest beyond 18 weeks of age could result in deterioration in the quality of the forage. Farmers should use 3 days irrigation interval at Kadawa rather than the daily conventional method of irrigation in order to save labour cost. Further studies on irrigated leguminous forages in combination with cereal and vegetable crops should be conducted to create awareness to farmers and further evaluate the possibility of adoption of food-forage technology in Nigeria.

\section{References}

Abia, E. E. (2011). Nutritive value of Lablab purpureus forage cut at different stages of growth in Rabbit diets (p. 93, Unpublished M. Sc Thesis). Department of Animal Science, Ahmadu Bello University, Zaria, Nigeria. 
Abu, S. T., \& Malgwi, W. B. (2011). Spatial variability of soil physico-chemical properties in Kadawa irrigation project in Sudan savanna Agroecology of Nigeria. International Journal of Agricultural Research, 6(10), 714-735. http://dx.doi.org/10.3923/ijar.2011.714.735

Abubakar, H., Lemma, G., \& Rethman, N. F. G. (2006). Effect of Lablab purpureus and Vicia atropurpuria as an intercrop, or in a crop rotation, on grain and forage yields of maize in Ethiopia. Tropical Grasslands, 40, $111-118$

Adamu, G. K., Aliyu, A. K., \& Jabbi, A. M. (2014). Fertility assessment of soils under rice cultivation in Kadawa, Garun Mallam Local Government Kano State. Journal of Natural and Applied Science, 5(1), 1-8.

Adedeji, O. S., Obudu, C. E., Olayeni, T. B., Ameen, S. A., Amao, S. R., \& Ayandiran, T. A. (2009). Towards revitalization of the Nigerian Small Ruminant Livestock Sub-Sector-A Review (p. 669). Proceedings of the $14^{\text {th }}$ Annual Conference of Animal Science Association of Nigeria (ASAN) held in Ogbomoso, $14^{\text {th }}-17^{\text {th }}$ September.

Adegbite, A. A., Agbaje, G. O., Adegbite, L. O., Taiwo, L. B., \& Awodoyin, R. O. (2005). Comparative effects of Apron plus 50DS and soil amendment on the growth, yield and food components of soybean. African Journal of Biotechnology, 4(12), 1396-1400.

Adesoji, A. G., Abubakar, I. U., Tanimu, B., \& Labe, D. A. (2013). Influence of Incorporated Short Duration Legume Fallow and Nitrogen on Maize, American-Eurasian Journal of Agricultural \& Environmental Science, 13(1), 58-67.

Aganga, A. A., \& Tshwenyane, S. O. (2003). Lucerne, Lablab and Leucaena leucocephala Forages: Production and Utilization for Livestock Production. Pakistan Journal of Nutrition, 2(2), 46-53. http://dx.doi.org/10.3923/pjn.2003.46.53

Agishi, E. C. (1983). Forage legume and pasture development in Nigeria. In S. Nuru \& S. G. Ryan (Eds.), Agricultural Research ACIAR Proceeding (Series 4, pp. 79-87).

Agyemang, K., Okike, I., Makun, H. J., \& Magaji, S. O. (2000). Trade-offs between forage yields and feed quality of Lablab purpureus, and milk yields in relation to planting and harvesting schedules. Experimental Agriculture, 36(4), 435-451.

Akanvou, R. K. (2001). Quantitative understanding of the performance of upland rice-cover legume cropping systems in West Africa (p. 149). PhD Thesis, Wageningen University, The Netherlands.

Alemu, B., Melaku, S., \& Prasad, N. K. (2007). Effects of varying seed proportions and harvesting stages on biological compatibility and forage yield of oats (Avena sativa L.) and vetch (Vicia villosa R.) mixtures. Livestock Research for Rural Development, 19(12). Retrieved February 11, 2013, from http://www.lrrd.org/lrrd19/1/alem19012.htm

Alemu, Y. (2008). Formulation of rations for sheep and goats. Technical Bulletin (No. 16, p. 27). Ethiopian Sheep and Goat Productivity Improvement Program.

Amodu, J. T., Adamu, A. M., Adeyinka, I. A., Alawa, J. P., \& Jagede, J. O. (2005). The nutritive value of laboratory ensiled Lablab (Lablab purpureus) and millet (Pennisetum americanum). Tropical Grasslands, 39(2), 117-123.

Amodu, J. T., Adeyinka, I. A., \& Lakpini, C. A. M. (2004). Response of lablab varieties to farmyard manure in the northern Guinea Savanna of Nigeria. Tropical Grasslands, 38, 186-191.

Anthony, W., \& John, L. (2007). Lablab fact sheet for Grain and Graze. Tropical forages-An Interactive Selection Tool. CSIRO Sustainable Ecosystems (p. 5).

AOAC. (2000). Association of Official Agricultural Chemist. Official Methods of Analysis (16 $6^{\text {th }}$ ed.). Virlington, Virginia, USA.

Armstrong, K. L., Albrecht, K. A, Lauer, J. G., \& Riday, H. (2008). Intercropping Corn with Lablab Bean, Velvet Bean, and Scarlet Runner Bean for Forage. Crop Science, 48, 371-379. http://dx.doi.org/10.2135/cropsci2007.04.0244

Ayisi, K. K., Bopane, M. P., \& Pengelly, B. C. (2004) Assessment of the variation in growth and yield of diverse lablab (Lablab purpureus ) germplasm in Limpopo Province, South Africa. In A. M. Whitbread \& B. C. Pengelly (Eds.), ACIAR proceedings (No. 115, pp. 44-50). Tropical Legumes for Sustainable Farming Systems in Southern Africa and Australia. 
Ball, D. M., Collins, M., Lacefield, G. D., Martin, N. P., Mertens, D. A., Olson, K. E., ... Wolf, M. W. (2001). Understanding Forage Quality (p. 20). American Farm Bureau Federation Publication 1-01, Park Ridge, IL.

Birnin-Yauri, H. B., \& Umar, S. (2014). Determination of yield and nutrient quality of herbage in Giron Masa grazing reserve, Kebbi State. IOSR Journal of Agriculture and Veterinary Science, 7(2), 60-64. http://dx.doi.org/10.9790/2380-07226064

Birteeb, P. T., Addah, W., Jakper, N., \& Addo-Kwafo, A. (2011). Effects of intercropping cereal-legume on biomass and grain yield in the savannah zone. Livestock Research for Rural Development, 23(198). Retrieved December 23, 2013, from http://www.lrrd.org/lrrd23/9/birt23198.htm

D’Souza, M. R., \& Devaraj, V. R. (2013). Oxidative stress biomarkers and metabolic changes associated with cadmium stress in hyacinth bean (Lablab Purpureus). African Journal of Biotechnology, 12(29), 4670-4682.

Delgado, C., Rosegrant, M., Steinfeld, H., Ehui, S., \& Courbois, C. (1999). Livestock to 2020: The Next Food Revolution. Food, Agriculture and the Environment Discussion Paper 28. International Food Policy Research Institute, Washington.

Dierenfeld, E. S., Lukuyu, B., \& Nyagaka, D. (2014). Nutrient Composition of Pastures in Kayunga District, Uganda: A Preliminary Investigation with Implications for Seasonal Supplementation in Grazing Ruminants. American Journal of Plant Sciences, 5, 985-989. http://dx.doi.org/10.4236/ajps.2014.57111

Egharevba, P. N. (1984). The effect of planting pattern on the performance of mixed sorghum and cowpea. Samaru Journal of Agricultural Research, 2(1\&2), 57-66.

Falaki, A. M., \& Mohammed, I. B. (2011). Performance of some Durum wheat varieties at Kadawa, Kano State of Nigeria. Bayero Journal of Pure and Applied Sciences, 4(1), 48-51. http://dx.doi.org/10.4314/bajopas.v4i1.10

Gbaraneh, L. D., Ikpe, F. N., Larbi, A., Wahua, T. A. T., \& Torunana, J. M. A. (2004). The Influence of Lablab (Lablab purpureus) on Grain and Fodder Yield of Maize (Zea mays) in a Humid Forest Region of Nigeria. Journal of Applied Science and Environmental Management, 8(2), 45-50.

Gilberto, C. J., \& Ladaslav, S. (2013). Recovery of nitrogen fixation after short-term flooding of the nodulated root system of soybean. Journal of Plant Physiology, 170, $235-241$. http://dx.doi.org/10.1016/j.jplph.2012.10.006

Harris, F. (1998). Indigenous intensification of agriculture: The Kano close-settled zone. Seminar on local knowledge in tropical agricultural research and development. Tropical Agriculture Association, September $26^{\text {th }}, 1998$ Anthropology Department, University of Durham.

Hubbard Feeds. (2014). Calf to Cow Replacement Heifer Program - Hubbard Feeds. Retrieved February, 2014, from http://www.HubbardFeeds.com

Iken, J. E., \& Amusa, N. A. (2004). Maize research and production in Nigeria. African Journal of Biotechnology, 3(6), 302-307.

Iker, H., Leonor, A., \& Sergi, M. B. (2011). Plant aging and excess light enhance flavan-3-ol content in Cistus clusii. Journal of plant physiology, 168(2), 96-102. http://dx.doi.org/10.1016/j.jplph.2010.06.026

International Institute of Tropical Agriculture (IITA) (2011). Doubling maize production in Nigeria. Retrieved February 26, 2014, from http://www. aflasafe.com

International Livestock Research Institute (ILRI). (1995). Field methods for measuring primary productivity of pastures. In J. O. Gefu \& J. T. Amodu (Eds.), A Training Manual of a National Workshop on Forage Production and Management in Nigeria (21 $1^{\text {st }}-25^{\text {th }}$ October, 2004, pp. 28-36). National Animal Production Research Institute Shika, Kaduna State.

John, O. O. (2006). Exploring socio-economic niches for legumes in Western Kenya smallholder farming systems (p. 169). PhD Thesis, Wageningen University, The Netherlands.

Kabirizi, J., Mpairwe, D., \& Mutetikka, D. (2006). Improving dairy cattle productivity in smallholder farms in Uganda: Incorporating leguminous forages in farming systems. Uganda Journal of Agricultural Sciences, 12(1), 1-12.

Kabirizi, J., Mpairwe, D., \& Mutetikka, D. (2007). The Effect of Integrating Forage Legumes in Smallholder Crop/livestock Farming Systems on Food, Fodder and Animal performance. Conference on International 
Agricultural Research for Development (October 9-11, 2007, pp. 1-7). University of Kassel-Witzenhausen \& University of Göttingen.

Karachi, M. (1997). Growth and nutritive value of lablab purpureus accessions in semi-arid Kenya. Tropical Grasslands, 31, 214-218.

Mahdi, Z., Rajab, C., Eslam, M., H., Mohammad, R. B., \& Kourosh, O. (2011). Gene action of some agronomic traits in corn (Zea mays L.) using diallel cross analysis. African Journal of Agricultural Research, 6(3), 693-703.

Malami, B. S., \& Sama'ila, M. (2012). Effects of Inter and Intra Row Spacing on Growth Characteristics and Fodder Yield of Cowpea (Vigna unguiculata (L.) Walp. Var. Kanannado) in the Semi-Arid North-Western Nigeria. Nigerian Journal of Basic and Applied Science, 20(2), 125-129.

Manyong, V. M., Ikpi, A., Olayemi, J. K., Yusuf, S. A., Omonona, R., \& Idachaba, F. S. (2003). Agriculture in Nigeria: Identifying Opportunities for Increased Commercialization and Investment. Main Report (p. 160).

Mapiye, C., Mwale, M., Mupangwa, J. F., Mugabe, P. H., Poshiwa, X., \& Chikumba, N. (2007). Utilization of ley legumes as livestock feed in Zimbabwe. Tropical Grasslands, 41, 84-91.

McIntire, J., Bourzat, D., \& Pingali, P. (1992). Crop-livestock Interaction in Sub-Saharan Africa. Washington, D. C. The World Bank.

Minson, D. J., Cowan, T., \& Havilah, E. (1993). Northern dairy feedbase. Summer pasture and crops. Tropical Grasslands, 27,131-149.

Mkamilo, G. S. (2004). Maize-Sesame intercropping in Southeast Tanzania: Farmers practices and perceptions and intercrop performance (p. 112). PhD Thesis, Wageningen University, The Netherlands.

Mohankumar, R., Girijesh, G. K., Krishnamurthy, N., Reddy, V. C., \& Vageesh, T. S. (2012). Yield potential, biological feasibility and economic viability of maize (Zea mays) and local field bean (Dolichos lablab L.) intercropping system in southern transitional zone of Karnataka. World Research Journal of Agronomy, 1(1), $1-3$.

Mokoboki, H. K., Ndlovu, L. R., \& Ayisi, K. K. (2002). Chemical and physical parameters of forage legume species introduced in the Capricorn region of Limpopo Province, South Africa, South African Journal of Animal Science, 32(4), 247-255.

Mortimore, M., Essiet, E. U., \& Patrick, S. (1990). The nature, rate and effective limits of intensification in the small holder farming system of Kano Closed-Settled Zone. Federal Agricultural Coordinating Unit, Ibadan, Nigeria.

Mpairwe, D. R., Sabiiti, E. N., Ummuna, N. N., Tegegne, A., \& Osuji, P. (2003). Integration of forage legumes with cereal crops. I. Effects of supplementation with graded levels of lablab hay on voluntary food intake, digestibility, milk yield and milk composition of crossbred cows fed maize-lablab stover or oats-vetch hay ad libitum. Livestock Production Science, 79, 193-212. http://dx.doi.org/10.1016/S0301-6226(02)00176-8

Mupangwa, J. F., Ngongoni, N. T., \& Hamudikuwanda, H. (2006). The effect of stage of growth and method of drying fresh herbage on chemical composition of three tropical forage legumes. Tropical and Subtropical Agroecosystems, 6, 23-30.

Murphy, A., \& Colucci, P. E. (1999). A tropical forage solution to poor quality ruminant diets: A review of Lablab purpureus. Livestock Research for Rural Development, 11, 2. Retrieved from http://www.cipav.org.co/lrrd//rrd11/2/colu.htm

Murungweni, C., Mabuku, O., \& Manyawu, G. J. (2004) Mucuna, Lablab and Paprika calyx as substitutes for commercial protein sources used in dairy and pen-fattening diets by smallholder farmers in Zimbabwe. In A. M. Whitbread \& B. C. Pengelly (Eds.), ACIAR Proceedings (No. 115, pp. 126-135).

Nasiru, O. M. O., \& Odusina, O. A. (2008). Economic evaluation of Irrigated Maize Farms towards boosting maize productivity: A case study of Epe LGA, Lagos state. American-Eurasian Journal of Scientific Research, 3(1), 19-23.

Ngongoni, N. T., Mwale, M., Mapiye, C., Moyo, M. T., Hamudikuwanda, H., \& Titterton, M. (2007). Evaluation of cereal-legume intercropped forages for smallholder dairy production in Zimbabwe. Livestock Research for Rural Development, 19(129). Retrieved May 31, 2014, from http://www.lrrd.org/lrrd19/9/ngon19129.htm 
NRC, Nation Research Council. (1985). Nutrient Requirements of sheep (6th ed.). Subcommittee on Sheep Nutrition, Committee on Animal Nutrition, Board on Agriculture, Nation Research Council, National Academy Press, Washington, D.C. Retrieved from http://www.sheep.cornell.edu

Nwoke, F. I. O. (1983). Effects of plant age on photoperiodic induction and development of flowers and fruits in Abelmoschus esculentus (L.) Moench. Journal of plant physiology, 110(5), 393-400.

Nworgu, F. C., \& Ajayi, F. T. (2005). Biomass, dry matter yield, proximate and mineral composition of forage legumes grown as early dry season feeds. Livestock Research for Rural Development, 17(11). Retrieved March 20, 2014, from http://www.lrrd.org/lrrd19/9/ngon19129.htm

Nyambati, E. M., \& Sollenberger, L. E. (2003). Nutritive value of top-canopy herbage of Mucuna and Lablab relay cropped in maize in the sub-humid highlands of northwestern Kenya. Tropical and Subtropical Agroecosystems, 1, 81-86.

Olufajo, O. O. (1995). Sorghum/Soyabean intercropping as affected by cultivar and plant arrangement in a sub humid tropical environment. Samaru Journal of Agricultural Research, 12, 3-11.

Omokanye, A. T., Amodu, J. T., \& Onifade, O. S. (1996). Effects of Phosphorus and Harvest Time on Dry Matter Yield, Nitrogen and Phosphorus Contents of Horsegram (Macrotyloma uniflorum). Tropicultura, 14(2), 73-76.

Omokanye, A. T., Amodu, J. T., \& Onifade, O. S. (2004). Influence of intra-row plant spacing, phosphorus application and growth stage on the forage, seed yields and quality of Phasey bean (Macroptilium lathyroides) in sub-humid area of Nigeria. Nigerian Journal of Animal Production, 31(1), 45-50.

Omokanye, A. T., Onifade, O. S., Amodu, J. T., \& Kallah, M. S. (2000). Research note: The performance of forage germplasm in a screening trial at Shika, Nigeria. Tropical Grasslands, 35, 48-52.

Onifade, O. S., Hena, S. W., Ibrahim, I. R., Olorunju, S. A. S., \& Agishi, E. C. (1998). The effect of variety and time of cut on yield and nutritive value of lablab forage. In O. O. Oduguwa, A. O. Fanimo, \& A. O. Osinowo (Eds.), Proceedings of the Silver Anniversary Conference of the Nigerian Society for Animal Production (NSAP) and the Inaugural Conference of the West African Society for Animal Production (WASAP) (March 21-26 ${ }^{\text {th }}, 1998$, p. 650). Gateway Hotel, Abeokuta.

Onifade, O. S., Omokanye, A. T., \& Amodu, J. T. (2001). The influence of seed rate and fertilizer type on growth of Tridax procumbens in Subhumid Nigeria. Tropicultura, 19(2), 70-74.

Onyibe, J. E. (2005). Effect of Irrigation Regime on Growth and Development of Two Wheat Cultivars (Triticum aestivum L.) in the Nigerian Savanna. Journal of Agriculture and Rural Development in the Tropics and Subtropics, 106(2), 177-192.

Oyinlola, E. Y., \& Chude, V. O. (2011). Status of available micronutrients of the basement complex rock-derived Alfisols in Northern Nigeria Savanna. Tropical and Subtropical Agroecosystems, 12, 229-237.

Pengelly, B. C., \& Maass, B. L. (2001). Lablab purpureus (L.) Sweet - diversity, potential use and determination of a core collection of this multi-purpose tropical legume. Genetic Resources and Crop Evolution, 48, 261-272. http://dx.doi.org/10.1023/A:1011286111384

Purseglove, J. W. (1968). Tropical Crops, Dicotyledons (pp. 273-276). Vol L London, UK: Longmans Greens and Company Ltd.

Rashid, S. (2010). Economic feasibility of integrated nutrient management for sustainable rainfed maize-legume based intercropping systems (p. 331). PhD Thesis submitted to the Department of Agronomy University of Rawalpindi, Pakistan.

Robert, E., Sarah, A. T., \& Andrew, D. P. (1997). The effect of plant age and nodulation on isoflavonoid content of red clover (Trifolium pratense L.). Journal of Plant Physiology, 150(5), 603-610. http://dx.doi.org/10.1016/S0176-1617(97)80326-4

Ron, K. (2005). Phosphorus requirements of different species, phytase feeding and ration formulation. Retrieved February 25, 2013, from http://www.puyallup.wsu.edu

Sani, B. M., Abubakar, I. U., Falaki, A. M., Mani, H., \& Jaliya, M. M. (2014). Grain Yield and Yield Components of Quality Protein Maize Genotypes as Influenced by Irrigation and Plant Population in the Nigerian Savannah. Journal of Agricultural Science, 6(4), 166-172. http://dx.doi.org/10.5539/jas.v6n4p166

Sani, B. M., Oluwasemire, K. O., \& Mohammed, H. I. (2008). Effect of Irrigation and Plant Density on the 
Growth, Yield and Water use Efficiency of Early Maize in the Nigerian Savanna. Asian Research Publishing Network Journal of Agricultural and Biological Science, 3(2), 1-12.

Shehu, Y., Alhassan, W. S., Pal, U. R., \& Phillips, C. J. C. (2001a). The effect of sowing date on the growth and nutritive value of Lablab purpureus. Journal of Agronomy and Crop Science, 186(1), 21-29. http://dx.doi.org/10.1046/j.1439-037x.2001.00454.x

Shehu, Y., Alhassan, W. S., Pal, U. R., \& Phillips, C. J. C. (2001b). The effects of plant population density on the growth and chemical composition of Lablab purpureus grown for fodder production in a semi-arid region. $\begin{array}{llllll}\text { Journal of Agronomy and Crop } & \text { Science, } & 186(2), 89 .\end{array}$ http://dx.doi.org/10.1046/j.1439-037X.2001.00455.x

Shehu, Y., Alhassan, W. S., Pal, U. R., \& Phillips, C. J. C. (2001c). Yield and chemical composition responses of Lablab purpureus to Nitrogen, Phosphorus and Potassium fertilizers. Tropical Grasslands, 35(3), 180-185.

Soneye, A. S. O. (2014). Farm holdings in northern Nigeria and implication for food security: a remote sensing and Gis assessment. African Journal of Food, Agriculture, Nutrition and Development, 14(2), 1-15.

SPSS. (2009). Statistical Package for Social Sciences. Pc version 17.0. Michigan Avenue, Chicago IIIinois, USA.

Van Soest, P. J., Robert, J. B., \& Lewis, B. A. (1991). Method for dietary fiber, neutral detergent fiber and non-starch polysaccharides in relation to animal nutrition. Journal of Dairy Science, 74, 3583-3597. http://dx.doi.org/10.3168/jds.S0022-0302(91)78551-2

Yusufali, A. N. (2005). Response of field bean (Dolichos lablab L.) genotypes to date of sowing and seed rate for fodder production and quality (p. 79). M.Sc Thesis. Department of Agronomy, University of Agricultural Sciences, Dharwad, India.

\section{Copyrights}

Copyright for this article is retained by the author(s), with first publication rights granted to the journal.

This is an open-access article distributed under the terms and conditions of the Creative Commons Attribution license (http://creativecommons.org/licenses/by/3.0/). 